\title{
The criminalization of torture in South Africa
}

\author{
Lovell Fernandez and Lukas Muntingh
}

\begin{abstract}
This article describes the politics related to the criminalization of torture in South Africa. It studies the differences between torture as an international crime and as a crime under international human rights law. The South African anti-torture law is analysed and critiqued against the standards and provisions set out in the United Nations Convention against Torture and Other Cruel, Inhuman or Degrading Treatment or Punishment. The article recommends amendments to the South African law, aimed at making the combating of torture more effective.
\end{abstract}

\section{Introduction}

The South African Constitutions of both 1993 (Interim Constitution) ${ }^{1}$ and 1996 (Final Constitution) made provision for the right to be free from torture and not to be treated or punished in a cruel, inhuman and degrading way. Even before the first democratic elections of 1994, the then National Party government of South African had signed the United Nations Convention against Torture and Other Cruel, Inhuman or Degrading Treatment or Punishment (UNCAT) in 1993. The new African National Congress government ratified it in 1998, thus signifying that a democratic South Africa would take its obligations under international human rights law seriously. In July 2013, South Africa incorporated UNCAT into national law by enacting the Prevention and Combating of Torture of Persons Act (PCTPA). ${ }^{2}$ Until then, acts of torture were punishable under the common law as either common assault or assault with intent to commit grievous bodily harm. These types of assault attracted lesser punishments than the kind of punishment envisaged under UNCAT. Besides, where the police were charged with acts amounting to torture, it was the cabinet minister responsible who was held to account under civil law in his official capacity, and not the perpetrator himself, as provided under UNCAT.

This article is divided into three parts. The first deals with the history and politics related to the passing of the PCTPA. The second studies the differences between torture as a crime under international criminal law and as a crime under international human

\footnotetext{
${ }^{1}$ Sec 11 provides: "Freedom and security of the person: (1) Every person shall have the right to freedom and security of the person, which shall include the right not to be detained without trial. (2) No person shall be subject to torture of any kind, whether physical, mental or emotional, nor shall any person be subject to cruel, inhuman or degrading treatment or punishment."

${ }^{2}$ Act 13 of 2013 .
} 
rights law. The final section analyses South African anti-torture law against the background of the benchmarks set by UNCAT.

\section{The historical and political background to South Africa's anti-torture law}

The euphoria of freedom in the early 1990 s soon faded when violent crime in South Africa rose to unprecedented levels. The public became frightened and demanded action from the government. The then President Mandela went so far as to resort to a metaphor of war to emphasize the urgent need to act, stating in his opening address to Parliament in 1995 that it was time "to take the war to the criminals" and not to permit a "situation in which we are mere sitting ducks". 3 The public outcry against spiralling crime became increasingly provocative, exemplified by the refrain "criminals have more rights than victims". 4 In general, political and public sentiment had become less than tolerant of the procedural rights that criminal suspects and prisoners had come to enjoy under the democratic constitution. Reports by oversight bodies about serious violations committed at the hands of the police and prison officials attracted scant public attention;5 only exceptional accounts regarding the assault and torture of suspects and prisoners drew a measure of sympathy. The unrelenting prevalence of violent crime, coupled with the government's obsession with tougher law enforcement, made it a challenging environment in which to advocate for an anti-torture law.

With Parliament reluctant to take up the issue of torture, NGOs stepped into the breach. From 2002, when the Robben Island Guidelines ${ }^{6}$ were endorsed by the African Commission of Human and Peoples' Rights, 7 NGOs started urging the government to criminalize torture. The issue of torture and other forms of inhuman and degrading treatment became the subject of a number of South African publications ${ }^{8}$ and court cases. The need to criminalize torture also arose, against the background of the findings of the South African Truth and Reconciliation Commission, which recorded

\footnotetext{
${ }^{3}$ Opening of Parliament address by President Mandela, 17 February 1995, Cape Town.

${ }^{4}$ See A du Plessis and A Louw "Crime and crime prevention in South Africa: 10 years after" (2005) 2 Canadian Journal of Criminology and Criminal Justice 427 at 437. See also M Schönteich "Criminal justice policy and human rights in the new South Africa" (2003) 3 Queensland University of Technology Law Review 1 at 3.

${ }^{5}$ See Independent Complaints Directorate (ICD) “Annual report 1998-99" at 24-26 and ICD "Annual report 2000-01" at 2.

${ }^{6}$ See JB Niyizurugero (ed) Preventing Torture in Africa (proceedings of a joint Association for the Prevention of Torture and African Commission on Human and Peoples' Rights workshop, Robben Island, South Africa, 12-14 February 2002) (2003, Association for the Prevention of Torture). The guidelines are the first instrument in the African system for the protection of human rights, specifically designed to combat torture.

${ }^{7}$ Res 61 (XXXII) 02: "Resolution on guidelines and measures for the prohibition and prevention of torture, cruel, inhuman or degrading treatment or punishment in Africa" (2002).

${ }^{8}$ See L Fernandez "Optional Protocol to the Convention against Torture and Other Cruel, Inhuman or Degrading Treatment or Punishment" (2005) 1 Law, Democracy and Development 136; L Muntingh Guide to the UN Convention against Torture in South Africa (2005, Civil Society Prison Reform initiative, Community Law Centre, University of the Western Cape); L Muntingh and L Fernandez "A review of measures in place to effect the prevention and combating of torture with specific reference to places of detention in South Africa" (2008) 24 South African Journal on Human Rights 123; L Muntingh "Children deprived of their liberty: Protection from torture and ill treatment" in A Van Niekerk, S Suffla and M Seedat (eds) Crime, Violence and Injury in South Africa: $21^{\text {st }}$ Century Solutions for Child Safety (2012, Psychological Society of South Africa) 162, available at: <http://www.mrc.ac.za/crime/Chapter12.pdf> (last accessed 1 March 2013); L Muntingh L and Z Satardien "Sexual violence in prisons - Part 1: The duty to provide safe custody and the nature of prison sex" (2011) 24 South African Journal of Criminal Justice 1; L Muntingh "The betrayal of Steve Biko: South Africa's initial report to the UN Committee against Torture and responses from civil society" (2008) 1 Law Democracy and Development 178. See also D Bruce "Police brutality in South Africa" in N Mwanajiti, P Mhlanga, M Sifuniso, Y Nachali-Kambikambi, M Muuba and M Mwanayanda (eds) Police Brutality in Southern Africa (2002, Afronet) 101.
} 
4,800 incidents of torture under the apartheid regime, including the period during which the commission sat.9 Criminalizing torture would not only fulfil the government's moral obligation owed to the freedom fighters who were murdered or mutilated at the hands of the apartheid police, but would also demonstrate a firm resolve to hold torturers legally and personally accountable for their conduct. Indeed, it was the death in police custody of the South African student leader Steve Biko in 1977 that prompted the UN General Assembly to commence work on what became UNCAT.10

\section{Emerging jurisprudence}

In its 2008 decision in the case of Mthembu $v S$, the Supreme Court of Appeal refused to follow the tendency of the courts under the apartheid regime not to exclude evidence obtained under torture. The court pointed out that, in the pre-constitutional era, the courts readily admitted all relevant evidence, regardless of how it was obtained, subject only to the judge's discretion to disallow it if the strict rules of admissibility would have the effect of operating unfairly against the accused. Real evidence, meaning an object (such as a knife, document or photograph) that becomes evidence following proper identification, was more readily admitted because its admission was governed by statute. The reason for this "was that such evidence usually bore the hallmark of objective reality compared with narrative testimony that depends on the say-so of a witness". ${ }^{11}$ Citing the UNCAT definition of torture in full, the court emphasized that the absolute prohibition against torture, even in the event of a public emergency, is a peremptory norm of international law that the South African Constitution follows, and it extended the non-derogation principle to include cruel, inhuman and degrading treatment: "[t]he absolute prohibition on the use of torture in both our law and in international law therefore demands that 'any evidence' which is obtained as a result of torture must be excluded "in any proceedings"'.12 Mthembu was an important decision as it pointed the way for other courts regarding the admissibility of evidence obtained by improper means.

In 2006, when the UN Committee against Torture (CAT), which oversees the implementation of UNCAT, was assessing South Africa's initial report, it was informed of a particularly brutal assault that prison officials had carried out on prisoners in the St Albans prison in Port Elizabeth in July 2005, reportedly in retaliation for the fatal stabbing of a warder. In deliberations with CAT, the South African government evaded the allegations and stated that, as the matter was subject to a civil claim, it was sub judice. ${ }^{13}$ The prisoners were denied access to medical treatment and legal representation until September 2005. One prisoner, McCallum, assisted by legal counsel, made numerous fruitless attempts to have the mass assault investigated and to seek relief. In 2008 he

\footnotetext{
9 Truth and Reconciliation Commission Report (1998, Juta \& Co), vol 2, chap 3, para 220. For torture under apartheid, see also D Foster, D Davis and D Sandler Detention and Torture in South Africa (1987, James Currey) at 1-35; and L Fernandez "Police abuses of non-political criminal suspects: A survey of practices in the Cape Peninsula area" (Institute of Criminology UCT Research Report Series, report 1-91).

${ }^{10}$ NS Rodley and M Pollard The Treatment of Prisoners under International Law (2009, Oxford) at 44.

${ }^{11}$ Mthembu v S (64/2007) [2008] ZASCA 51, para 22.

${ }^{12} \mathrm{Id}$, para 32.

${ }^{13}$ CAT/C/SR.739, para 57.
} 
lodged an individual petition with the UN Human Rights Committee (HRC). ${ }^{14}$ In its view, released in 2010, the HRC found that his right to be free from torture, protected by article 7 of the International Covenant on Civil and Political Rights (ICCPR), had been violated. 15 The HRC ordered the South African authorities to conduct a thorough and complete investigation and prosecution of those who were responsible, and to provide the victim with adequate compensation. The South African government did not respond to the decision until almost a year later, when the South African Human Rights Commission brought the matter before the Parliamentary Portfolio Committee on Correctional Services (now the Parliamentary Portfolio Committee on Justice and Correctional Services). ${ }^{16}$ The Department of Correctional Services' response was that had it been informed beforehand that the outcome would have been different. This was, of course, untrue, as the HRC had on five occasions invited the South African government to respond. ${ }^{17}$ The Parliamentary Portfolio Committee on Correctional Services subsequently took up the broader issue of torture and held public hearings on the prevalence of torture in November 2011, which indicated a growing awareness of the absolute prohibition of torture.18 The McCallum decision turned out to be extremely embarrassing, for it not only indicated multiple system failures on the part of the state to protect the rights of prisoners, but revealed the inept manner in which the government had interacted with the HRC. In December 2012, the World Organization against Torture (OMCT) called upon the South African authorities to implement the HRC's views by undertaking a prompt, thorough and complete investigation and prosecution of those who were responsible, and by providing McCallum and the other victims with full and adequate compensation. ${ }^{19} \mathrm{~A}$ civil damages suit was subsequently brought against the minister of correctional services in the Port Elizabeth High Court, but at the time of writing the matter had not yet been concluded.

\section{Other law reform}

In 2011 the then existing police oversight body, the Independent Complaints Directorate, was replaced by the Independent Police Investigative Directorate (IPID) under a new law, the Independent Police Investigative Directorate Act 1 of 2011 (IPID Act), compelling the IPID to investigate allegations of torture. However, at the time, there was no statutory definition of torture. During the public hearings that were held on the IPID Bill, it was proposed that the IPID Act should define torture, even if only as an interim measure, as the definition of torture was key to the IPID discharging its mandate effectively. The Parliamentary Portfolio Committee on Police was concerned

\footnotetext{
${ }^{14}$ See Bradley McCallum v South Africa comm no 1818/2008, UN doc CCPR/C/100/D/1818/2008 (2010), paras 2.5 and 2.9.

${ }^{15}$ ICCPR, art 7: "No-one shall be subjected to torture or to cruel, inhuman or degrading treatment or punishment. In particular, no-one shall be subjected without his free consent to medical or scientific experimentation."

16 Telephone interview with Ms J Cohen, parliamentary programme, SA Human Rights Commission, 3 December 2011 (copy on file with the authors).

${ }_{17}^{17}$ CCPR/C/100/D/1818/2008, para 4.

${ }^{18}$ Parliamentary Monitoring Group (PMG) report on the meeting of the Parliamentary Portfolio Committee on Correctional Services on 29 November 2011, available at: http://www.pmg.org.za/report/20111130-stakeholder-hearings-prevalence-torture-correctionalcentres (last accessed 28 December 2011).

19 "South Africa: OMCT calls for the effective implementation of the decision of the Human Rights Committee for acts of torture and other forms of ill-treatment" (26 November 2012), available at: <http://www.omct.org/monitoringprotectionmechanisms/statements/south-africa/2012/11/d22041/> (last accessed 20 August 2013).
} 
about the bill's lack of a definition of torture, as this would make it difficult to determine which acts constituted torture and on what grounds the IPID would conduct an investigation of torture. The committee evidently decided that it was not going to deal with the absence of a definition of torture, thereby implying that it was a task for the Portfolio Committee on Justice. ${ }^{20}$ It can, however, be concluded that at least the Portfolio Committee on Police realised the importance of criminalizing torture and may thus have alerted the Portfolio Committee on Justice and Constitutional Development to the urgent need for such legislation.

South Africa's initial report to CAT became due in 1999. It appears to have prompted some response from the government at the time and the Department of Justice and Constitutional Development (as it then was) selectively circulated a draft act to criminalize torture in 2003. A few stakeholders submitted comments, ${ }^{21}$ but the process was halted until a second version was circulated in 2005. Both versions exhibited notable shortcomings. ${ }^{22}$ By the time CAT assessed South Africa in November 2006, no notable progress had been made towards tabling the draft legislation before Parliament. CAT requested detailed information within one year on progress made regarding the act, 23 but this information was never submitted to CAT.

In 2008, the Department of Justice circulated a third version of the proposed act for comment. Once again, there were notable shortcomings in the text, most importantly the fact that the definition of torture excluded the phrase "for such purposes as", thus considerably narrowing the scope of the crime of torture. A number of civil society organizations made submissions on the act but, when the act was eventually tabled in May 2012, there was little evidence that these submissions, or the submissions on earlier versions of the act, had changed its substance. In September 2012 the Portfolio Committee on Justice and Constitutional Development held public hearings and nine civil society organizations made submissions. ${ }^{24}$ The submissions, in general, encouraged the legislature to seize the opportunity to provide for as comprehensive legislation as possible in order to promote compliance with UNCAT. However, for reasons that are not clear, but possibly for the sake of expediency, the committee adopted a narrow focus and, with the exception of a few minor amendments, adopted the version that had been tabled in Parliament. One notable exception is that the act now includes provisions for adherence to the principle of non-refoulement (which forbids rendering a true victim of persecution to his or her persecutor), which had not been

\footnotetext{
${ }^{20}$ PMG report on the meeting of the Portfolio Committee on Police of 3 August 2010, available at: <https://pmg.org.za/committeemeeting/11782/> (last accessed 13 August 2015)

${ }^{21}$ For example, in July 2012, two NGOs, the Civil Society Prison Reform Initiative and the National Institute for Crime Prevention and the Reintegration of Offenders, made a joint submission. See, for example, Civil Society Prison Reform Initiative "Submissions on Combating of Torture of Persons Bill” [B 21 of 2012, 31 July 2012] at 1.

${ }^{22}$ L Muntingh and L Fernandez (2006) "Civil Society Prison Reform Initiative submission to the UN Committee against Torture, in response to 'Republic of South Africa: First country report on the implementation of the Convention Against Torture, and Other Cruel, Inhuman and Degrading Treatment or Punishment"”, available at <www2.ohchr.org/English/bodies/cat/docs/CSPRI.doc> (last accessed 31 July 2015).

${ }^{23} \mathrm{CAT} / \mathrm{C} / \mathrm{ZAF} / \mathrm{CO} / 1$, para 28.

${ }^{24}$ PMG report on the meeting of the Portfolio Committee on Justice and Constitutional Development on 4 September 2012, available at: $<$ https://pmg.org.za/committeemeeting/14822/> (last accessed 16 August 2015).
} 
included in the tabled version. When the act was referred to the second house of Parliament, the National Council of Provinces, it was adopted without any requests for amendment. ${ }^{25}$ On 25 July 2013, President Zuma assented to the act and four days later it was gazetted. ${ }^{26}$

\section{Regional developments in combating torture}

South Africa's push to criminalize torture needs to be seen within the context of similar initiatives being undertaken in several other African countries. In 2008, also as a result of a UN Human Rights Committee review, Madagascar became the first country in the Southern African Development Community to criminalize torture in a law which also guarantees reparations to victims of torture. ${ }^{27}$ In 2009 Uganda criminalized torture in accordance with UNCAT, as well as cruel, inhuman and degrading treatment or punishment at the hands of a public official. ${ }^{28}$ In 2011 the Democratic Republic of the Congo recognized torture as a discrete crime in its Penal Code, with a definition in accordance with UNCAT; ${ }^{29}$ since the law was passed, several public officials have been sentenced to up to life imprisonment for acts of torture.30 Other African states that have passed anti-torture laws are Burundi (2009), Senegal (1996) and Cameroon (1997). ${ }^{31}$ In 2011 the Kenyan government drafted the Prevention of Torture Act in collaboration with civil society groups. However, at the time of writing this act had not yet been tabled before Parliament.

\section{The differences between torture as a crime under international human rights law and torture as a crime under international criminal law}

Although international human rights law, under which UNCAT resorts, and international criminal law, of which torture is a constituent international crime, are two distinct bodies of international law, they are intimately linked and reinforce each other as regards protection of the right to human dignity. ${ }^{2}$ Human rights law has imbued international criminal law with a greater sensitivity to the need to protect human dignity and to "safeguard life and limb as far as possible". 33 Given the fact that UNCAT is the only human rights treaty obliging states to criminalize torture as a discrete crime, it is instructive to discuss briefly how international criminal law and international human rights law deal with torture.

\footnotetext{
${ }^{25}$ PMG report on the meeting of the National Council of Provinces Standing Committee on Security and Constitutional Development on 20 May 2013, available at: <https://pmg.org.za/committee-meeting/15878/> (last accessed 8 August 2013).

${ }^{26}$ Act no 13 of 2013 Government Gazette no 36716 of 29 July 2013.

${ }^{27}$ See Act No 2008-008 against Torture and Other Cruel, Inhuman or Degrading Treatment or Punishment, arts 1, 2 and 4.

${ }^{28}$ See of the Prevention and Prohibition of Torture Act No 3 of 2012, arts 2, 3, 4 and 7.

${ }^{29}$ See Redress Trust Torture in Africa: The Law and Practice (2012, Redress Trust) at 14.

30 See "The United Nations welcome that "Criminalization of torture in the DRC is moving forward", available at: <http://www.ohchr.org/EN/NewsEvents/Pages/DisplayNews.aspx?NewsID=13517\&LangID=E> (last accessed 13 August 2015).

${ }^{31}$ See Redress Trust Torture in Africa, above at note 29 at 12-14. At the regional level, the African Commission on Human and Peoples' Rights commenced work in late 2014 on a general comment on art 5 of the African Charter on Human and Peoples' Rights, with specific reference to torture and providing redress to victims of torture. See "Concept paper on the development of a general comment on article 5 of the African Charter on Human and Peoples' Rights" at 1-5, available at: <http://www.achpr.org/files/news/2015/05/d182/concept_paper.pdf> (last accessed 13 August 2015).

${ }^{32}$ See A Cassese International Criminal Law (2nd ed, 2008, Oxford) at 6; F Jessberger "Bad torture: Good torture" (2005) 3 Journal of International Criminal Justice 1059 at 1068 and 1071; G Werle Principles of International Criminal Law (2nd ed, 2009, Asser Press) at $45-47$.

${ }^{33}$ Cassese, ibid.
} 


\section{The definition of torture under UNCAT}

Article 1 of UNCAT defines torture as

"Any act by which severe pain or suffering, whether physical or mental, is intentionally inflicted on a person for such purposes as obtaining from him or a third person information or a confession, punishing him for an act he or a third person has committed or is suspected of having committed, or intimidating or coercing him or a third person, or for any reason based on discrimination of any kind, when such pain or suffering is inflicted by or at the instigation of or with the consent or acquiescence of a public official or other person acting in an official capacity. It does not include pain or suffering arising only from, inherent in or incidental to lawful sanctions."

The UNCAT definition of torture is now widely accepted as reflecting customary international law. 34 It has been used as a tool by national courts, 35 regional human rights courts $3^{36}$ and UN ad hoc criminal tribunals. ${ }^{37}$ The objective elements of the crime of torture under UNCAT are: the conduct must result in severe physical or mental suffering; the harm must be inflicted intentionally; the conduct must have a certain purpose; the perpetrator must be a public official or someone acting in an official capacity; and the torture excludes pain and suffering arising only from or inherent in acts which are lawfully sanctioned. The mens rea requirement is criminal intent. This means that negligent conduct can never be considered to be torture, although it can constitute cruel and inhuman conduct. ${ }^{8}$

\footnotetext{
${ }^{34}$ See Prosecutor v Delalić and Others ICTY TC II, 16 November 1998 (IT-96-21-T), para 459; and Prosecutor v Furundžija judgment no IT-95-17/1-T, trial chamber, 10 December 1998, para 11. However, in Prosecutor v Kunarac and Others, IT-96-23/-23/1-T, trial chamber, 22 February 2001, para 482, the trial chamber of the International Criminal Tribunal for the Former Yugoslavia (ICTY) stated that the definition of torture in UNCAT "cannot be regarded as the definition of torture under customary international law which is binding regardless of the context in which it is applied". The Appeals Chamber confirmed this view, though in a differentiated way, stating that the UNCAT definition of torture "reflects customary international law as far as the obligation of states is concerned" and "must be distinguished from an assertion that this definition wholly reflects customary international law regarding the meaning of the crime of torture generally": IT-96-23/-23/1-A, Appeals Chamber, 12 June 2002, para 147. While this decision has been followed in subsequent decisions of the ad hoc tribunals (see, for example, Prosecutor v Semanza ICTR-97-20, Appeals Chamber, 20 May 2005 , para 248 and Prosecutor v Limaj et al IT-03-66, trial chamber, 30 November 2005, para 240), the ad hoc tribunals have, in earlier decisions on the question of "pain and suffering" considered reports of the UN Human Rights Committee as well as the case law of the European Court of Human Rights. For a criticism of the Kunarac judgments, see P Gaeta "When is the involvement of state officials a requirement for the crime of torture" (2008) 6 Journal of International Criminal Justice 183 at 188, note 10. See also, generally, on the ius cogens [peremptory norm] status of torture under international human rights law, Cassese, id at 151-52.

${ }^{35}$ See the South African Supreme Court of Appeals decision in Mthembu, above at note 11, paras 30-32, and the decision of the High Court of Kenya in Wakaba and Others v Attorney General (final judgment) Oxford Reports on International Law in Domestic Courts ILDC 1543 (KE 2010), paras 34-37.

${ }^{36}$ The first reference of the European Court of Human Rights to the definition of torture in UNCAT was in Selmouni v France (2000) 29 EHRR 403, para 100. See also Ilhan v Turkey (2000) 7 EHRR 36; Turkey (2000) 34 EHRR 17. The African Commission on Human and Peoples' Rights adopted the UNCAT definition of torture in Zimbabwe Human Rights NGO Forum v Zimbabwe, AfrCommmHPR, comm no 227/1999, 33rd session, 15-19 May 2003, para 70.

${ }^{37}$ See the early cases of Prosecutor v Akayesu ICTR-96-4, trial chamber, 2 September 1998, para 681 and Delalić, above at note 34, para 459. However, since the judgments in Kunarac, above at note 34, UNCAT's influence has diminished very significantly. For a full discussion, see C Burchard "Torture in the jurisprudence of the ad hoc tribunals" (2008) 6 Journal of International Criminal Justice 159 at $162-63$.

${ }^{38}$ M Nowak "What practices constitute torture? US and UN standards" (2006) 28 Human Rights Quarterly 810 at 830.
} 


\section{Torture as a crime against humanity under the ICC Statute}

The International Criminal Court (ICC) Statute defines the crime against humanity of torture as the "intentional infliction of severe pain or suffering, whether physical or mental, upon a person in the custody or under the control of the accused; except that torture shall not include pain or suffering arising only from, inherent in or incidental to, lawful sanctions".39

The mens rea requirement is that the perpetrator knew that the conduct was or was intended to be part of a widespread or systematic attack against a civilian population by a government or an organization. ${ }^{40}$ This definition draws on the element of "severe pain or suffering" contained in the UNCAT definition, except that the definition under the ICC Statute does not require that the conduct have a specific purpose. It is not clear why the purposive element is absent, although several speculations have been put forward, one of which is that the list of purposes would have to be an exclusive list of purposes. The former UN special rapporteur on torture, Sir Nigel Rodley, criticized this reasoning as "not wholly satisfying", leaving us "with an outcome that remains unsatisfactory". ${ }^{4}$ Instead of the specific purpose requirement, article 7(2)(e) of the ICC Statute imposes a new requirement which is not contained in earlier instruments defining torture, namely that the victim of torture be "in the custody or under the control of the accused". Compared to the UNCAT definition, this restriction does not seem to take account of the factual situation where the perpetrator does not have custody or control of the victims, but causes them severe mental pain by informing them of the severe pain being inflicted on their family members elsewhere. What is unclear is whether the perpetrator must control or have custody of the victim before inflicting the pain, or whether the pain and suffering must be inflicted beforehand in order to exercise custody and control.

\section{Torture as a war crime under the ICC Statute}

The ICC Statute regulates the war crime of torture for international armed conflicts 42 and for non-international armed conflicts. 43 The statute includes torture or inhuman treatment as constituting a grave breach of the 1949 Geneva Conventions, thus making each a war crime. 44 The crime of torture as a crime against humanity and the war crime of torture do not, as UNCAT does, require the perpetrator to act in an official

\footnotetext{
${ }^{39}$ ICC Statute, art 7(2)(e).

${ }^{40} \mathrm{Id}$, arts 7(1) and 7(2). Torture is listed in art 7(1)(f) as part of the definition of a "crime against humanity". Art 30 stipulates generally that criminal responsibility is incurred only if the material elements of the crime "are committed with intent and knowledge".

${ }^{41}$ NS Rodley "The definition(s) of torture in international law" (2002) 55 Current Legal Problems 467 at 492 . See also CK Hall in O Triffterer (ed) Commentary on the Rome Statute of the International Criminal Court (2nd ed, 2008, CH Beck) at 254 (art 7, note 481) who wonders whether, given the anarchic, random and purposeless way in which crimes against humanity have been committed in the past few decades, often by neighbours and completely undisciplined forces, far removed from any conduct or acts aligned to carrying out a state's or organization's policy, conceptual consistency (ie by including the purposive element) might not be to the detriment of victims. K Ambos Internationales Strafrecht [International Criminal Law] (4th ed, 2014, CH Beck) at 300, marginal 208, rejects the need for a purposive element, arguing in support of a 2001 decision of the German Federal High Court (BGHSt 46,295) that torture consists of causing severe physical or mental pain and that this need not be in pursuit of a specific goal; all that is required is that the infliction of the pain is intentional.

${ }^{42}$ ICC Statute, art 8(2)(a)(ii).

${ }^{43} \mathrm{Id}$, art 8(2)(c)(i).

${ }^{44}$ Id, art 8(2)(a).
} 
capacity. However, as under UNCAT, the war crime of torture requires that the pain or suffering inflicted must serve specific purposes. There is a dispute among the chambers of the international tribunals about whether the list of purposes is exhaustive. Whereas some trial chambers have preferred the open phrasing used in the UNCAT definition of torture, 45 others have favoured an exhaustive list. 46

The elements of crime in the ICC Statute, which carry over the UNCAT list of purposes, introducing it with the words "such as" speak in favour of a non-exhaustive list. 47

The differences between the definition of torture under international human rights law and international criminal law are unavoidable, for the contexts within which the crime is perpetrated differ. The essential difference between UNCAT and torture under international criminal law is twofold. First, under UNCAT the discrete crime of torture is punishable as such, irrespective of whether it is committed in war or peacetime, or in the context of widespread and systematic violence against civilians. Secondly, under UNCAT there must be direct or indirect involvement of a state official, an "implicit approval or condonation by the authorities",48 to avoid a single act of torture committed by a private person against another private person being considered criminal under international law. Under UNCAT, criminal liability arises where state agents, who enjoy special coercive powers vested in them by the state, abuse such powers with impunity. 49

To sum up, UNCAT has been very useful in breathing meaning into the definition of torture in the fields of both international criminal law and international human rights law. The UNCAT definition of torture has guided both the International Criminal Tribunal for the Former Yugoslavia (ICTY) and International Criminal Tribunal for Rwanda, which have no definition of torture in their enabling statutes. As one writer states, UNCAT "must be considered the standard, to the extent that its guiding considerations can be transferred to international criminal law".50

\section{The state obligation to criminalize torture under UNCAT}

UNCAT distinguishes itself from other human rights treaties in that it compels states to criminalize torture, including attempts to commit it, as well as complicity or participation in torture. ${ }^{11}$ States parties are required to make these offences punishable by penalties that reflect the gravity of the crime. $5^{2}$ While UNCAT does not prescribe a minimum penalty, one author considers a term of imprisonment of between six and 20

\footnotetext{
${ }^{45}$ See, for example, Delalić, above at note 34, para 470; Limaj, above at note 34, para 253.

${ }^{46}$ See, for example, Kunarac, above at note 34, para 48; Prosecutor v Simić et al ICTY TC 17 October 2003 (IT-95-9), para 79.

${ }^{47}$ See Rodley "The definition(s) of torture", above at note 41 at 484.

${ }^{48}$ Cassese International Criminal Law, above at note 32 at 189.

${ }^{49}$ See, for example, in Delalić, above at note 34, para 510. See also Rodley "The definition(s) of torture", above at note 41 at 485 ; and Gaeta "When is the involvement of state officials", above at note 34 at 190.

${ }^{50}$ Werle Principles of International Criminal Law, above at note 32 at 319. See also K Dörmann "Article 8:War crimes" in Triffterer (ed) Commentary on the Rome Statute, above at note 41 at 306 on UNCAT's guiding role in the development of the jurisprudence in international humanitarian law. See also Jessberger "Bad torture", above at note 32 at 1071.

${ }^{51}$ UNCAT, art 4(1).

${ }^{52} \mathrm{Id}$, art 4(2).
} 
years appropriate, a conclusion reached on the basis of views expressed by individual members of CAT.53 Whereas in earlier years some commentators on UNCAT held the view that criminalizing torture at the domestic level did not necessarily mean that states parties enact a specific crime corresponding to UNCAT's definition of torture, CAT has over the years shifted from urging states to enact a separate and distinct crime of torture to the point of requiring them to do so, 54 even where national law criminalizes the physical abuse of a person by a public official.55 In its July 2012 decision in Belgium $v$ Senegal, the International Court of Justice stated that that the obligation to criminalize torture has to be implemented as soon as the state is bound by UNCAT. In the words of the court: "[t]his obligation ... has in particular a preventive and deterrent character, since by equipping themselves with the necessary legal tools to prosecute this type of offence, the States parties ensure that their legal systems will operate to that effect and commit themselves to co-ordinating their efforts to eliminate any risk of impunity". ${ }^{56}$ Had the present Sudanese president, Omar Al Bashir, for whom the ICC issued an arrest warrant in March 2009,57 attended the inauguration of President Zuma in May 2009 or the football World Cup which South Africa hosted in 2010, South Africa would have been obliged to ensure that he was arrested and prosecuted for, amongst other international crimes, the crime of torture as a crime against humanity. Bashir chose to avoid such a situation by not attending these events.

However, South Africa's obligations under the ICC Statute did not absolve it from the duty to enact a separate crime of torture, in line with its obligations under UNCAT, which it had ratified. In 2013 South Africa enacted an anti-torture law which criminalizes torture as a discreet crime. The next section discusses this law.

\section{The South African prevention and combating of torture of persons act 58}

The PCTPA defines torture as:

"any act or omission, by which severe pain and suffering, whether physical or mental, is intentionally inflicted on a person for such purposes as to (i) obtain information or a confession from him or her or any other person; or (ii) punish him or her for an act

\footnotetext{
${ }^{53}$ C Ingelse The UN Committee Against Torture: An Assessment (2001, Kluwer) at 342.

${ }^{54}$ N Rodley and M Pollard "Criminalisation of torture: State obligations under the United Nations Convention against Torture and Other Cruel, Inhuman and Degrading Treatment or Punishment” (2006) 2 European Human Rights Law Review 115 at 119.

55 See CAT's concluding observations on the report submitted by Germany at 3 , available at: <http://www2.ohchr.org/english/bodies/cat/docs/co/CAT.C.DEU.CO.5_en.pdf> (last accessed 31 July 2015). A case in point is sec 340 of the German Criminal Code, which imposes a punishment of up to five years' imprisonment on a public official who, in carrying out his duties, commits a bodily injury or allows it to be committed. In November 2011, CAT nevertheless expressed "serious concern" (at 1) that the provision does not "adequately punish the infliction of pain and suffering, whether physical or mental as required by article 1 of the Convention". As to the need to criminalize torture in the national law, see also CAT's concluding observations on the reports submitted by Bulgaria (CAT/C/BGR/CO/4-5), Ethiopia (CAT/C/SR.974 and 975), Turkey (CAT/C/SR.975) and Ghana (CAT/C/SR.1011). See also report of the special rapporteur on torture and other cruel, inhuman or degrading treatment or punishment: A/HRC13/39, para 46, where he emphasizes the fact that the UNCAT definition of torture makes no mention of any bodily injuries or lasting impairment, though injuries can be an aggravating factor.

${ }^{56}$ International Court of Justice "Questions relating to the obligation to prosecute or extradite" (Belgium v Senegal), judgment of 20 July 2012, general list no 144, available at: 〈http://www.icj-cij.org/docket/files/144/17064.pdf> (last accessed 14 August 2012 ), para 75.

${ }^{57}$ See Prosecutor v Omar Al Bashir (Decision on the Prosecutor's Application for a Warrant of Arrest against Omar Hassan Ahmed Al Bashir) ICC-02/05-01/09-3 (4 March 2009).

${ }^{58}$ Act 13 of 2013.
} 
he or she or any other person has committed, is suspected of having committed or is planning to commit; or (iii) intimidate or coerce him or her or any other person to do, or to refrain from doing, anything; or for any reason based on discrimination of any kind, when such pain or suffering is inflicted by or at the instigation of, or with the consent or acquiescence of a public official or other person acting in an official capacity, but does not include pain or suffering arising only from, inherent in or incidental to lawful sanctions".59

\section{Critique of the key elements of the act}

The PCTPA gives effect to UNCAT by requiring that a public official or someone acting in an official capacity be involved in the torture. Rodley expressed the rationale for state involvement as follows: "[t]he fundamental idea is that, as is conceptually appropriate in the context of giving legal norms to human rights principles, the state violates the right through its agents, human rights being the normative articulation of the fundamental rules mediating the relationship of the organs of society - typically the state - and the individual members of society".60

Accordingly, neither the worst form of abuse nor the most inhuman treatment of a person will be regarded as constituting torture under UNCAT unless the state participates in it. ${ }^{61}$ The drafters of UNCAT excluded private acts of torture from the definition on the assumption that these could be dealt with under ordinary, domestic criminal law. ${ }^{62}$ This raises problems, discussed below, when private persons are contracted by public officials to carry out the torture. A private person can commit torture if the private person's act is carried out with the acquiescence or consent of a public official. As Rodley puts it: "[i]t may also be someone with no official status acting in collusion with, and to advance the purposes of officialdom, often to shroud the responsibility of members of that officialdom". 63

Whereas UNCAT does not define a "public official", PCTPA specifies that a public official "means any person holding public office and exercising or purporting to exercise a public power or a public function in terms of any legislation". ${ }^{64}$ The phrase "to exercise a public power or a public function" could be interpreted to have a more expansive meaning, beyond the conventional understanding of "official capacity". It suggests someone who is exposed to the public and who is regarded as an authoritative public figure, exercising authority publicly. This could, by implication, include persons who, by virtue of their authority, position and influence, do in fact or are likely to exercise power over people. For example, African traditional chiefs and headmen, who wield considerable

\footnotetext{
${ }^{59} \mathrm{Id}, \mathrm{sec} 3$.

${ }^{60}$ Rodley "The definition(s) of torture", above at note 41 at 484.

${ }^{61}$ GH Miller Defining Torture (2005, Flooerscheimer Center for Constitutional Democracy, Benjamin N Cardozo School of Law) at 17.

${ }^{62} \mathrm{JH}$ Burgers and H Danelius The United Nations Convention Against Torture: A Handbook on the Convention against Torture and Other Cruel, Inhuman, or Degrading Treatment or Punishment (1988, Martinus Nijhoff Publishers) at 119-20; Miller, ibid.

${ }^{63}$ Rodley "The definition(s) of torture", above at note 41 at 485 .

${ }^{64}$ PCTPA, sec 1.
} 
public authority, have no clearly defined legal status, 65 although they are recognized by the constitution as "traditional authorities". ${ }^{66}$ They, too, are bound by any international agreements which South Africa has ratified, ${ }^{67}$ including those relating to human rights.

A loophole in UNCAT's definition of the perpetrator is that it does not provide for torture by persons who are not acting in an official capacity but who, because of their public authority, are within the compass of those who are likely to commit torture. Examples include private security police who are contracted to the government, and off-duty policemen. A recent case is $F v$ Minister of Safety and Security and Another ${ }^{68}$ which involved the use of brutal force by an off-duty policeman. The facts were as follows. An off-duty policeman on standby and clad in civilian clothes was driving an unmarked police vehicle in the early hours of the morning. He stopped to give a lift to a 13 year old girl, who accepted the lift, feeling that it would be safe to do so. Along the way, the policeman stopped the vehicle, assaulted the girl and then raped her. The girl laid criminal charges for assault and rape against the policeman, who was found guilty on both charges and sentenced to 12 years' imprisonment, five of which were suspended. Thereafter she brought a damages suit against the minister of police and the policeman in the Cape Town High Court, which found the minister vicariously liable for the damages suffered as a result of the policeman's delictual conduct. The minister appealed to the Supreme Court of Appeal, which overturned the High Court decision on the grounds that the police officer was off-duty at the time and that the minister was, therefore, not liable. The girl appealed to the Constitutional Court which, in a precedent-setting judgment, unanimously set aside the order of the Supreme Court of Appeal on the basis that the connection between the conduct of the policeman and his employment was sufficiently close to make the minister vicariously liable for the policeman's unlawful acts. ${ }^{69}$ Amongst the factors that the court considered was that the girl looked to the policeman because of his employment as a policeman (a deduction she made from the visible dockets and police radio in the vehicle), "which placed him in a position of trust", a trust which he abused in view of her vulnerability and helplessness. 70

Other institutions contracted to the state or that are privately owned or run could include children's homes, youth hostels and rehabilitation centres. Although they are private institutions, they still fulfil a state function, and their personnel are for all intents and purposes acting in an official capacity, carrying out a state-sanctioned

\footnotetext{
${ }^{65}$ See Department of Provincial and Local Government "A discussion document towards a white paper on traditional leadership and institutions" (11 April 2000) at 29, para 7.2, available at: <http://www.gov.za/sites/www.gov.za/files/trad_0.pdf> (last accessed 31 July 2015).

${ }^{66} \mathrm{Sec} 211$ of the South African Constitution (1996).

${ }^{67}$ Id, sec 231(4). Although there is no evidence of local chiefs having being involved in torture, cases have been reported in which alleged so-called "witches" (sorcerers) have been tortured to death in two provinces in areas within the jurisdiction of traditional leaders. As regards the difficulties in policing and prosecuting such cases, see T Petrus "Defining witchcraft-related crime in the Eastern Cape Province of South Africa" (2011) 3 International Journal of Sociology and Anthropology 1.

${ }^{68} 2012$ (1) SA 536 (CC).

${ }^{69} \mathrm{Id}$, para 80.

${ }^{70} \mathrm{Id}$, paras 78 and 80.
} 
function, even though they are not paid by the state. The definition in the PCTPA of a public official, therefore, needs to include employees of such private institutions.

Although the PCTPA does not specifically use the term "private person", one may infer from a reading of section 3 that a private person may incur liability for torture where such a person acts "at the instigation of, or with the consent or acquiescence of a public official". This necessarily excludes private persons acting on their own. Several writers have criticized the failure of states to enact a separate crime of torture which covers acts of brutality that occur in the private sphere. ${ }^{71}$ At the public hearings preceding the passing of the PCTPA, several human rights groups submitted that torture be extended to cover sex workers, rape against women and other acts of violence against women and children. ${ }^{72}$ In its submission, Amnesty International argued that the bill (as it then was) should criminalize torture without the need to show a nexus to the involvement of public officials.73 What is often overlooked here is that article 1(2) of UNCAT leaves it open to states to enact separate legislation "which does or may contain provisions of wider application" than those contained in article 1 of UNCAT.

\section{The purposive element}

UNCAT's definition of torture requires that the severe physical or mental pain inflicted on the person must be "for such purposes as": to obtain information or a confession from the victim or another person; to punish, intimidate, intimidate or coerce the victim or another; or to discriminate against the victim or another person on any ground.74 All these purposes apply to situations where the victim is at least under the effective power or control of the person who administers the pain and suffering, using his advantageous situation to achieve a certain effect. The purpose requirement is the main distinguishing feature between torture and cruel or inhuman treatment.75 The purposes listed in the UNCAT definition are now recognized as having attained the status of customary international law, 76 and most writers are of the view that they are merely illustrative and do not constitute an exhaustive list.77 This interpretation is inferred

\footnotetext{
${ }^{71}$ See, for example J Sarson and L McDonald "Torture of Canadian women by non-state actors in the private sphere: A shadow report" (2008), available at: <http://www2.ohchr.org/english/bodies/cedaw/docs/ngos/VOWCanada42.pdf> (last accessed 21 March 2012); BC Meyersfeld "Reconceptualizing domestic violence in international law" (2003) 67 Albany Law Review 371 at 401-13. See also M Nowak "Report of the special rapporteur on torture and other cruel, inhuman or degrading treatment or punishment" (2010) $\mathrm{A} / \mathrm{HRC} / 13 / 39$.

72 See joint submission of the Women's Legal Centre and the Sexual Workers Education and Advocacy Taskforce, as well as submission of the Centre for Applied Legal Studies, available at: <http://khulumani.net/active-citizens/item/687-report-on-submissionstothe-public-hearings-on-the-torture-bill.html> (last accessed 23 July 2013).

${ }^{73}$ See Amnesty International "Written submission to the Portfolio Committee on Justice and Constitutional Development, Parliament of South Africa: The Prevention and Combating of Torture of Persons Bill" (31 July 2012) at 3, available at: <https://pmg.org.za/committee-meeting/14822/> (last accessed 3 July 2015).

${ }^{74}$ UNCAT, art 1.

${ }^{75}$ See the decisions of the European Court of Human Rights (ECtHR) in Egmez v Cyprus 2000-XII CHR 315 at 336, and Denizci v Cyprus 2001-VI ECHR 225 at 312-13.

${ }^{76}$ Prosecutor v Krnojelac IT-97-25-T trial chamber, 15 March 2002, para 185. See also Kunarac, above at note 34, paras 485 and 497.

${ }^{77}$ See, for example, Nowak "What practices constitute torture?", above at note 38 at 831 ; Hall in Triffterer (ed) Commentary on the Rome Statute, above at note 41 at 254; K Kittichaisaree International Criminal Law (2001, Oxford) at 111; D Weissbrodt and C Heilman "Defining torture and cruel, inhuman and degrading treatment" (2011) 29 Law and Inequality 343 at 386 and 387 ; A Montavon-McKillip "CAT among pigeons: The convention against torture, a precarious intersection between international and human rights law and US immigration law” (2002) 44 Arizona Law Review 247 at 255. See also Delalić above at note 34, paras 470-71. See
} 
from the phrase "such purposes as", which precedes the purposes listed, connoting that other, similar purposes may be included as long they resemble the purposes listed expressly.78 It is not required that the conduct must be perpetrated solely for a prohibited purpose, as it suffices where the prohibited purpose is part of the motivation underlying the conduct and need not necessarily be the predominate or only purpose.79 For example, there is nothing illegitimate in obtaining information or a confession from someone, so long as this is within the law and not through torture. A common characteristic of these purposes is that they are all in some way connected "precisely to state purposes or, at any rate, the purposes of an organized political entity exercising effective power". ${ }^{80}$

The PCTPA replicates the purposes listed in the UNCAT definition and introduces them, like UNCAT, with the words "for such purposes as". This is an improvement on the original wording of the PCTPA in which no such prefix was used, which meant that the enumerated list of purposes was exhaustive. The departure from the original wording is in part attributable to the strong criticism by human rights groups during the public hearings that were held before the law was enacted. Adherence to the UNCAT wording is important in two ways. First, it shows a preparedness to commit unvaryingly to the efforts to make the struggle against torture more uniform internationally. Secondly, the open list of purposes will enable the courts to expand the list of prohibited purposes. Indeed, the UN ad hoc tribunals, which have adopted a definition of torture similar to that of UNCAT, have expanded the list of prohibited purposes. In Prosecutor $v$ Furundžija the court added the "humiliation" of the victim to the possible purposes of torture. ${ }^{81}$ In Kunarac and Others the ICTY Appeals Chamber confirmed that, if one prohibited purpose is fulfilled by the conduct, "the fact that such conduct was also intended to achieve a non-listed purpose (even one of a sexual nature) is immaterial". 82

\section{Defences}

The aim of UNCAT is to prevent states from resorting to torture, no matter what the circumstances. ${ }^{8} 3$ In line with UNCAT, 84 the PCTPA upholds the absolute, non-derogable character of the prohibition against torture. Section 4(3) of the PCTPA states that the fact that the person charged with the torture is a "head of State or government, a member of a government or parliament, an elected representative or a government official; or was under a legal obligation to obey a manifestly unlawful order of a government or superior" is neither a defence nor a ground for reducing the sentence once the person has been convicted. Section 4(4) reinforces the absoluteness and non-

also R St J Macdonald "International prohibitions against torture and other forms of similar treatment and punishment" in Y Dinstein (ed) International Law at a Time of Perplexity: Essays in Honour of Shabtai Rosenne (1989, Martinus Nijhoff Publishers) 385 at 390.

${ }^{78}$ Burgers and Danelius The United Nations Convention, above at note 62 at 186.

${ }^{79}$ Delalić, above at note 34 , para 470.

${ }^{80}$ Rodley "The definition(s) of torture", above at note 41 at 484 . See also Nowak "What practices constitute torture?", above at note 38 at 832; and Burgers and Danelius The United Nations Convention, above at note 62 at 119.

${ }^{81}$ Above at note 34, para 162.

${ }^{82}$ Above at note 34 , para 155.

${ }^{83}$ Compare with CAT/C/CR/30/6, in which CAT recommended that Belgium's Penal Code have a provision preventing the raising of the defence of a state of necessity to violate the right not to be tortured.

${ }^{84}$ UNCAT, art 2(2). 
derogability of the prohibition by stating that even "a state of war, threat of war, internal political instability or any other public emergency may not be invoked as a justification for torture". Furthermore, the act absolves from punishment anyone who disobeys an order to commit torture.

The effect of this absolute prohibition is that no defence whatsoever can be invoked against a charge of torture.85 And no substantive ground for excluding criminal liability, such as self-defence or a state of necessity, is admissible as a defence. A more contentious issue is whether the crime of torture, as a crime under international human rights law, is subject to prescription. Article 6 of the UN Basic Principles and Guidelines on the Right to a Remedy and Reparations for Victims of Violations of International Human Rights and Humanitarian Law (2005) provides that prescription "shall not apply for prosecuting violations of international human rights and humanitarian law norms that constitute crimes under international law", but makes this subject to the proviso "where so provided for in an applicable treaty or contained in other international obligations". In the case of Barrios Altos (Chumbipuma and Others $v$ Peru) the Inter-American Court of Human Rights asserted that "it is unacceptable to use ... statutes of limitations ... as a means of preventing the investigation and punishment of those responsible for gross human rights violations such as torture ... which are prohibited as breaches of non-derogable rights recognized under international human rights law". ${ }^{86}$ However, because there is scant evidence of state practice in this area, it cannot be conclusively established whether the inapplicability of prescription is now part of customary international law. ${ }^{87}$

In recent times, particularly in the wake of the 9/11 attacks in the United States, the categorical non-derogable ban of torture by international law has been put into question by many government officials, including those in democratic states. The use of torture is being justified on the grounds that it is a necessary tool to deal with "the global war on terror", "exceptional circumstances", "unique situations" or an "unrivalled and critical security challenge". 88 Such justifications conveniently brush aside the fact that the human right to dignity is not only the foundation for human rights law, but as also stated in the preamble to the Universal Declaration of Human Rights, the foundation of "freedom justice and peace in the world". The need to protect the inviolability of human dignity is non-negotiable, and cannot be balanced against any opposing interests, including the right to life of a hostage. As Jessberger argues: "[a]ny exception to this position would implicate the risk of abuse and open the door to a dangerously slippery slope. Only a clear position that establishes criminal liability for

\footnotetext{
${ }^{85}$ Compare with CAT/C/CR/33/3, 2004 (concluding observations on the United Kingdom), paras 4(a) and 5(a). See also Association for the Prevention of Torture "The criminalisation of torture under the UN Convention Against Torture and Other Cruel, Inhuman or Degrading Treatment or Punishment: An overview for the compilation of torture laws" (2009) at 5.

${ }^{86}$ Judgment of 14 March 2001, para 41.

${ }^{87}$ See Werle Principles of International Criminal Law, above at note 32 at 248-49 with regard to the applicability of the statutes of limitation to international crimes.

${ }^{88}$ See "Report of the special rapporteur on torture and other cruel, inhuman or degrading treatment or punishment": UN doc A/HRC/13/39/Add.5 (2010) at 16.
} 
all acts of torture without exception can guarantee that torture is not routinely applied in difficult cases".89

\section{The non-inclusion of cruel, inhuman or degrading treatment or punishment}

What is regrettable is that the South African act does not criminalize cruel, inhuman and degrading treatment or punishment in accordance with article 16 of UNCAT. This shortcoming has been rightly criticized by NGOs. 90 The omission reflects a narrow understanding of UNCAT, the drafters of which clearly intended liability for torture to attach not only to the torturer, but also to any other person whose conduct might well exclude the cumulative elements of the crime of torture, but whose acts or omissions still amount to cruel, inhuman or degrading treatment or punishment. It is precisely for this reason that UNCAT has been fortified with the Optional Protocol to the Torture Convention (OPCAT), which provides for a system of regular visits by independent bodies to places where people are involuntarily deprived of their liberty, to prevent torture and other cruel, inhuman or degrading treatment or punishment, 91 an instrument which South Africa has promised to ratify although it has not yet done so. Whether ratification will follow now that the law has been enacted remains to be seen. According to the Association for the Prevention of Torture, South Africa has stated that its ratification of OPCAT will be subject to a declaration that will delay the designation of a national independent visiting body for three years. 92

The PCTPA is also deliberately silent on what procedure an alleged victim of torture should follow to have the matter investigated. UNCAT explicitly spells out the procedure that should be adhered to once an allegation of torture is made. States parties must ensure that the complaint is investigated promptly and impartially; 93 that the complainant has the right to have his complaint lodged with and examined promptly and impartially by competent authorities, and that both the complainant and witnesses be protected against ill-treatment or intimidation; 94 and that the victim of torture obtains redress within the law and has an enforceable right to fair compensation, including the means for rehabilitation.95 The PCTPA provides none of these assurances; all it says is that the cabinet minister concerned must develop programmes to assist and advise "any person who wants to lodge a complaint of torture". ${ }^{96}$

At the public hearings on the bill, most of the human rights groups emphasized the need to provide victims of torture with effective remedies. The submissions highlighted how

\footnotetext{
${ }^{89}$ Jessberger "Bad torture", above at note 32 at 1063.

90 See submissions of Lawyers for Human Rights, available at: <http://www.lhr.org.za/policy/lhr-submission-prevention-andcombatting-torture-persons-bill-b21-2012> (last accessed 15 August 2015).

${ }_{91}^{91}$ See art 1 of OPCAT, which was adopted by the UN General Assembly on 18 December 2002 (A/RES/57/199).

92 Association for the Prevention of Torture "South Africa: OPCAT situation" (19 July 2013), available at: <http://www.apt.ch/en/opcat_pages/opcat-situation-67/> (last accessed 20 July 2013).

${ }^{93}$ UNCAT, art 12.

${ }^{94} \mathrm{Id}$, art 13.

${ }^{95} \mathrm{Id}$, art 14.

${ }^{96}$ PCTPA, sec 9.
} 
state inaction against police abuse of power has come to shape perceptions of torture amongst victims. The Department of Justice and Constitutional Development acknowledged that some people believe that torture is authorized by the state and is therefore acceptable. In a joint submission, the Trauma Centre for Survivors of Violence and the South African No Torture Consortium pointed to the fact that victims who had been tortured for political reasons under apartheid are usually still not ready to report past incidents of torture and receive counselling, because they rationalized torture as part of the struggle against oppression. 97 These victims sought to address this trauma in a practical way, such as personal ideological preparation and as a promise of a better life. In its submission, the Centre for the Study of Violence elaborated on the need for the state to compensate survivors of torture without their having to go through the emotional and psychological strain that pursuing a civil claim entails.98 Several submissions underlined the need for the act to contain a definition of "victim" to include dependants or family of the actual victim, and others who may have been tortured for intervening on behalf of victims in distress. The act is unfortunately silent on all these matters. The fact that the act does not mention the word "victim" in its preamble or in its "objects" in section 2 is regrettable.

\section{Universal jurisdiction and immunities}

The act confers jurisdiction on South African courts to try a torture case if the suspect is a South African citizen, is ordinarily resident in South Africa, is "lawfully" in the country, or has allegedly committed the crime of torture against a South African citizen or against a person who is ordinarily resident in the country. 99 It contains a general provision which grants universal jurisdiction to South African courts if the suspect has allegedly committed the crime of torture outside South Africa, but only if the National Director of Public Prosecutions (NDPP) consents to the prosecution in writing. ${ }^{100}$ Article 6(2) of UNCAT would still require a preliminary inquiry, from the time the suspect arrives in the country, before the case is submitted to the NDPP. If the NDPP finds that there is sufficient evidence to prosecute, but another state party to UNCAT requests that the suspect be extradited, South Africa could dispense with the need to prosecute by acceding to the request. On this point, the International Court of Justice held in Belgium $v$ Senegal that "the choice between extradition or submission for prosecution, pursuant to the Convention, does not mean that the alternatives are to be given the same weight. Extradition is an option offered to the State by the Convention, whereas prosecution is an international obligation under the Convention, the violation of which is a wrongful act engaging the responsibility of the State". ${ }^{101}$

\footnotetext{
${ }^{97}$ See "Prevention and Combating of Torture of Persons Bill: Department of Justice, Centre for Study of Violence and Reconciliation, Trauma Centre \& SANToC briefings" (27 February 2013), available at: <https://pmg.org.za/committee-meeting/15469/> (last accessed 3 July 2015).

98 Ibid.

${ }^{99}$ PCTPA, sec 6(1).

${ }^{100} \mathrm{Id}, \sec 6(2)$.

${ }^{101}$ Above at note 56, para 95.
} 
The question is whether foreign heads of state and diplomats may be prosecuted for torture. Under international law, state officials enjoy functional immunity (ratione materiae or subject-matter immunity) from the jurisdiction of foreign courts for conduct carried out in their official capacity on behalf of their home state. This immunity does not lapse when the official no longer holds office, for their acts are ascribed to the state. ${ }^{102} \mathrm{~A}$ few classes of senior international officials, such as incumbent heads of state ${ }^{103}$ or government, diplomats, as well as ministers of foreign affairs, enjoy personal immunity (ratione personae or procedural immunity). The rationale for the immunity here is the "functional necessity", ${ }^{104}$ meaning that, given the need for such officials to conduct state affairs internationally, it is important to the functioning of their home state that they should have freedom of action. However, this immunity is valid only for prosecution by states and does not survive when the official ceases to hold office.105 Furthermore, international tribunals may indict high officials, such as heads of state and senior foreign affairs officials, who are suspected of having committed international crimes, even if they are still in office. ${ }^{106}$

By virtue of having domesticated the ICC Statute, South Africa, too, expressly excludes immunity for heads of state or government as well as government ministers and officials and members of Parliament. ${ }^{107}$ The contradiction here is that the Diplomatic Immunities and Privileges Act of 2001 exempts a head of state from the jurisdiction of South African civil and criminal courts. ${ }^{108}$ Dugard is of the view that this suggests that heads of state would not be entitled to plead immunity for crimes under the ICC Statute. ${ }^{109}$ This point of view was given currency in an historic decision of the North Gauteng High Court, Pretoria in May 2012 in the case of Southern African Litigation Centre and Another $v$ The National Director of Public Prosecutions and Others. ${ }^{110}$ This case dealt with whether, under the principle of universal jurisdiction, criminal investigations relating to allegations of the commission of torture as a crime against humanity may be instituted at the domestic level against persons who acted outside South Africa. In a widely celebrated judgment, the court held that the decision of the National Prosecuting Authority and the Priority Crimes litigation Unit not to initiate an investigation into acts of torture as a crime against humanity under the national law implementing the ICC Statute was "unlawful, inconsistent with the Constitution and therefore invalid". ${ }^{111}$ This decision was upheld by both the Supreme Court of Appeal

\footnotetext{
${ }^{102}$ See R Van Alebeek The Immunity of States and their Officials in International Criminal Law and International Human Rights Law (2008, Oxford) at 222.

${ }^{103}$ See J Dugard International Law: A South African Perspective (4th ed, 2008, Juta \& Co) at 253; Werle Principles of International Criminal Law, above at note 32 at 236. The immunity excludes heads of entities that do not qualify as a sovereign state. Van Alebeek, id at 113 .

${ }^{104}$ A Cassese International Human Rights Law (2008, Oxford) at 222; Cassese International Criminal Law, above at note 32 at 304.

${ }^{105}$ See Werle Principles of International Criminal Law, above at note 32 at 237-41.

106 Examples here are the indictment by the ICTY of Milošević whilst he was the incumbent president of the Federal Republic of Yugoslavia and the indictment by the Special Court for Sierra Leone of Taylor, when he was president of Liberia.

${ }^{107}$ See art 4(2) of the Implementation of the Rome Statute of the International Criminal Court Act, 27 of 2002.

108 Act 37 of 2001 , sec 4 .

${ }^{109}$ Dugard International Law, above at note 103 at 257. See also R v Bow Street Secondary Magistrate and Others, Ex parte Pinochet (No 3) [1999] 2 All ER 97 (HL).

${ }^{110}$ Case no 77150/09, available at: http://www.saflii.org/za/cases/ZAGPPHC/2012/61.pdf (last accessed 15 August 2015).

${ }^{111} \mathrm{Id}$, para 33.
} 
and Constitutional Court. The latter court highlighted that torture as a crime against humanity is proscribed under South Africa's national law under section 238 of the constitution and section 4(1) of the ICC Statute, that the South African police have the authority and obligation under international law to investigate, "in particular, high priority crimes like torture as a crime against humanity", and that "the customary international law nature of the crime of torture underscores the duty to investigate this type of crime". ${ }^{112}$ The Constitutional Court went on to add that the universal jurisdiction to investigate international crimes is not absolute, but is subject to the country with jurisdiction being unwilling or unable to prosecute, and to the investigation being confined to the territory of the investigating state.

There remains the issue of immunity from prosecution regarding a crime committed in violation of international human rights law, such as the crime of torture under UNCAT. This question arose in the Pinochet ${ }^{113}$ trial, in which a majority of the House of Lords held that personal immunity does not apply in the case of a criminal prosecution for torture, in view of the fact that torture is a violation of a peremptory norm of international law. Most of the Lords stated that allowing personal immunity would have been inconsistent with UNCAT's provisions granting universal jurisdiction. ${ }^{114}$ However, scholars differ on whether incumbent heads of state and senior state officials may assert personal immunity from prosecution before national courts of other jurisdictions. ${ }^{115}$ It is submitted that South African courts, when confronted with this question, would need to be guided by two crucial principles, namely that: "the prohibition of torture is part of customary international law and it has become a peremptory norm"; ${ }^{116}$ and UNCAT requires that the perpetrator be a public official or someone acting in an official capacity. In the authors' view, if a critical element of the crime of torture is that it is associated with the conduct of the state, it would make no sense to allow immunity to prevail. Akande and Shah articulate this argument more forcefully in the following words: "[s]ince the Torture Convention limits the offence of torture to acts committed in an official capacity, extra-territorial prosecution can occur only in cases where immunity ratione materiae [because of the nature of the matter] would ordinarily be applicable. However, application of immunity ratione materiae

\footnotetext{
${ }^{112}$ National Commissioner of the South African Police Service v Southern African Human Rights Litigation Centre and Another [2014] ZACC 30, para 60. See also National Commissioner, South African Police Service and Another v Southern African Human Right Litigation Centre and Another [2013] ZASCA 168.

113 Above at note 109 .

${ }^{114}$ Lords Brown Wilkinson, Saville, Millet and Phillips, id at 114, 169-70, 178-79 and 190, respectively. However, the position is different regarding civil claims; in the case of Al-Adsani v United Kingdom (2001) 34 EHRR 273, the ECtHR, by a majority of just one vote, allowed immunity to prevail in a case involving an allegation of torture against the government of Kuwait, the court holding that this was consistent with international law. In their comment on this decision, D Akande and S Shah "Immunities of state officials, international crimes, and foreign domestic courts" (2011) 21 European Journal of International Law 815 at 838 contend that "if the ECtHR had accepted the normative hierarchy theory and was of the view that the jus cogens prohibition prevailed over immunity in criminal cases, it is difficult to see how such a prohibition would also not override immunity in civil cases as well".

${ }^{115}$ See Van Alebeek The Immunity of States, above at note 102 at 294-95, especially at 294, note 406.

${ }^{116}$ Decision of the International Court of Justice in Belgium v Senegal, above at note 56 at 101, para 99. See also Filartiga v Pena-Irala 630 F.2d 876 at 884 (2nd cir 1980); A Bell and J Dona "Torturous intent: Refoulement of Haitian nationals and US obligations under the Convention against Torture" (2011) 35 New York University Review of Law and Social Change 707 at 714-15.
} 
would deprive the jurisdiction provisions of the Convention of practically all meaning. Such a result would be contrary to the object and purpose of the treaty ... " 117

\section{Lawful sanctions}

UNCAT's definition of torture specifically excludes "pain or suffering arising only from, inherent in or incidental to lawful sanctions". This exception remains the most controversial and problematic element in the definition of torture. ${ }^{118}$ Miller describes it as "the exception that swallowed the rule - allowing a state to avoid the prohibition on torture simply by sanctioning methods of punishment that involve extremely harsh treatment". ${ }^{119}$ The controversy centres on the fact that what may be regarded as a lawful sanction in one country could be unlawful in another. This results in an uneven and diverse implementation of UNCAT's definition of torture internationally.

One would think that the issue of lawful sanctions would not arise in South Africa, as penalties such as the death penalty, corporal punishment and forced hard labour are unlawful. However, practice shows that, despite the constitutional safeguards against the physical and psychological abuse of persons who are deprived of their liberty, conduct which would otherwise amount to torture or to cruel, inhuman or degrading treatment or punishment continues to occur, especially in police stations and prisons. ${ }^{120}$ The prison authorities recently admitted that assaults by officials which cause "severe pain over a period of time, also mental pain and suffering" would qualify as torture.121 However, prison authorities are at times lax in reporting such cases to the Parliamentary Portfolio Committee on Correctional Services (as it then was). ${ }^{122}$ The Judicial Inspectorate for Correctional Services is of the view that one of the consequences of torture only being prohibited by the Bill of Rights and not by any law governing correctional services is that "it is probable that torture loses its hierarchical importance in the genre of conduct of officials ..." ${ }^{123}$

Returning to the PCTPA, in its definition of torture, the act replicates the "lawful sanctions" exception in UNCAT's definition word for word, without any reference to an international benchmark, which would have been helpful. Here one may quote Sir Nigel Rodley, UN special rapporteur on torture in 1997, when he argued that:

"The lawful exclusion must necessarily refer to those sanctions that constitute practices widely accepted as legitimate by the international community, such as deprivation of

\footnotetext{
${ }^{117}$ Akande and Shah "Immunities of state officials", above at note 114 at 842.

${ }^{118}$ A Boulesbaa The UN Convention on Torture and the Prospects for Enforcement (1999, Martinus Nijhoff Publishers) at 31 , note 110.

${ }^{119}$ Miller Defining Torture, above at note 61 at 20.

${ }^{120}$ See generally Muntingh and Fernandez "A review of measures", above at note 8; L Muntingh Guide to the UN Convention Against Torture in South Africa (2011, Civil Society Prison Reform Initiative-Community Law Centre, University of the Western Cape) at 45-

52; T Ramagaga "The problem of torture in South African prisons" (2011, Institute of Security Studies), available at: <https://www.issafrica.org/iss-today/the-problem-oftorture-in-south-african-prisons> (last accessed 15 August 2015).

121 "Judicial Inspectorate for Correctional Services on its third quarter performance: Briefing on torture in correctional centres" (March 2012), available at: <http://www.pmg.org.za/report/20120307-judicial-inspectorate-correctional-services-its-sept-dec-2011-quarter> (last accessed 20 August 2012).

122 Ibid.

${ }^{123}$ Id at 4
} 
liberty through imprisonment, which is common to all penal systems. Deprivation of liberty, however unpleasant, as long as it comports with basic internationally accepted standards, such as those set forth in the United Nations Standard Minimum Rules for the Treatment of Prisoners, is no doubt a lawful sanction." 124

A similar view to that of Rodley was taken by the African Commission on Human and Peoples' Rights when it rejected Sudan's defence of its criminal law under which five girls were sentenced to a public lashing with a wire and a plastic whip on their bare backs. It held that " $[t]$ here is no right for individuals, and particularly the government of a country to apply physical violence to individuals for offences. Such a right would be tantamount to sanctioning state sponsored torture under the Charter and contrary to the very nature of this human rights treaty". ${ }^{125}$

While some countries have done away with the exception clause altogether in their implementing laws, thus tightening the definition of torture, others have either resisted such amendments ${ }^{126}$ or have clarified the meaning of "lawful sanctions" in their national laws. For example, Australia and New Zealand have qualified the "lawful sanctions" clause by adding after the word "sanctions" the words "that are not inconsistent with the Articles of the [ICCPR]". ${ }^{127}$ It is submitted that South Africa, too, should add this wording to the qualifying clause. A reference to the ICCPR would constitute a more extensive range of international norms, covering a wider category of vulnerable persons than, say, a reference to the Standard Minimum Rules for the Treatment of Prisoners would. An even better solution would be to apply the test according to which the enquiry would be whether the "lawful sanctions" limit the rights of the arrested or detained person under section 35 of the South African Constitution. If yes, the next stage of the enquiry would be whether the "lawful sanctions" can be justified "in an open and democratic society based on human dignity, equality and freedom" as stipulated in the limitations clause in section 36(1) of the constitution. The Constitutional Court has held that "[a]t the very least a law or action limiting the right to freedom must have a reasonable goal and the means for achieving that goal must also be reasonable."128

\section{Punishment}

Under the PCTPA, any public official who commits torture, attempts to commit torture, or "incites, instigates, commands or procures any person to commit torture is guilty of the offence of torture and is on conviction liable to imprisonment, including

\footnotetext{
${ }^{124}$ UN doc E/CN.4/1997/7, para 8.

${ }^{125}$ Doebbler v Sudan (2003) AHRLR 153 (ACHPR 2003), para 42.

${ }^{126}$ See Macdonald "International prohibitions", above at note 77 at 401-03 for the grounds for defeating a proposal that the "lawful sanctions" clause be referenced to international law.

${ }^{127}$ See division 274.2 (4) of the Australian Criminal Code Act, as amended by Crimes Legislation Amendment (Torture Prohibition and Death Penalty Abolition) Act 2010, and sec 2(b) of New Zealand's Crimes of Torture Act (Act 106 of 13 November 1989).

${ }^{128}$ Coetzee v Government of the Republic of South Africa, Matiso and Others v Commanding Officer, Port Elizabeth Prison and Others 1995 (10) BCLR 1382, para 11. See also S v Makwanyane and Another 1995 (6) BCLR 665, para 104 where the court held that, while there are no absolute standards for determining reasonableness and necessity, principles can be established, and these would have to be applied on a case by case basis.
} 
imprisonment for life". ${ }^{129}$ By prescribing a penalty of up to life imprisonment, the act reflects the gravity of the crime, thus giving effect to CAT's recommendation to South Africa that the penalty for torture should aim "to prevent and eliminate torture and combat impunity". ${ }^{130}$ The stiff tariff of punishment is aimed at ensuring that conduct which would otherwise be classed as a form of assault would attract a harsher punishment than has many times been the case until now. ${ }^{131}$

Unfortunately, the PCTPA does not categorize torture as one of the serious crimes that attract a discretionary minimum sentence, ${ }^{132}$ despite the fact that torture is regarded as an utterly abhorrent crime, "the most severe violation of human dignity", 133 "a crime of the highest order", 134 the prohibition of which is widely considered to be ius cogens [a peremptory norm]. The discretionary minimum provisions are meant to ensure that the courts impose a standardized, severe and consistent punishment for serious, listed crimes unless there are weighty grounds for imposing a lesser sentence. ${ }^{135}$ Subjecting someone found guilty of torture to a discretionary minimum sentence would show the universal condemnation of the torturer, the hostis humani generis ${ }^{136}$ [an enemy of all mankind], and would serve as a strong deterrent to any would-be torturer. By not stipulating a minimum sentence, the act creates the possibility that torturers are given a suspended sentence, which is clearly not in line with the spirit of UNCAT.

The PCTPA lists a number of factors ${ }^{137}$ to be taken into account when imposing sentence, but is vague on how the courts should interpret them. It is submitted that these need to be substituted with concrete aggravating factors such as the duration of the torture, its frequency, the nature of the detention, the victim's accessibility to medical and legal assistance, the severity of the mental and physical injuries suffered, and the number of persons who perpetrated the torture.

\section{Conclusion}

The PCTPA represents a significant and progressive development in the South African criminal justice system. It is the product of concerted efforts on the part of national and international human rights groups to bring the South African government to accept the need to prohibit torture and end the impunity with which it has been committed. More than this, it reinforces the only international human rights treaty that defines and criminalizes torture and which describes the manner in which its prohibition should be enforced at both the national and international level. The act represents a commitment to complying with the standards of UNCAT. However, in

\footnotetext{
${ }^{129}$ PCTPA, sec 4.

${ }^{130} \mathrm{CAT} / \mathrm{C} / \mathrm{ZAF} / \mathrm{CO} / 1$ at 3 , para 13.

131 For examples, see Redress Trust South Africa at 15, available at: <http://www.redress.org/downloads/countryreports/SouthAfrica.pdf> (last accessed 15 August 2015).

${ }^{132}$ See the Criminal Law Amendment Act 105 of 1977.

${ }^{133}$ Jessberger "Bad torture", above at note 32 at 1063.

${ }^{134}$ Bell and Dona "Torturous intent", above at note 116 at 737.

${ }^{135}$ S v Malgas 2001 (91) SACR (SCA), at part B of the summary. See also S v Mzayifani and Others (unreported, Eastern Cape High Court, Port Elizabeth, case no CC13/09, 30 January 2012).

${ }^{136}$ Filartiga v Pena-Irala, above at note 116 at 890.

137 See PCTPA, sec 5.
} 
order to give fuller effect to the range and reach of the prohibition set out in UNCAT, the act needs to be amended to provide for the criminalization of cruel, inhuman or degrading treatment or punishment. As regards the perpetrator element, the PCTPA needs to include persons in the employ of private institutions or organizations that are contracted to carry out work on behalf of the state. A separate law would be necessary to provide for torture in the private sphere as provided by article 1(2) of UNCAT. In order to ensure that torture does not take place under the guise of lawful sanctions, "lawful sanctions" need either to be qualified by a concluding clause referring to the relevant provisions in the ICCPR, or be tested by using the limitations clause in the constitution as a yardstick. The penalties for torture need to be categorized as under the discretionary minimum sentencing provisions, with clear guidelines as to how the aggravating factors should be interpreted.

Finally, the PCTPA has now prompted the Parliamentary Portfolio Committee on Justice and Correctional Services to propose changes in the current law that will limit the ability of someone charged with torture to obtain police bail and to be released with a warning in lieu of bail. ${ }^{138}$ Furthermore, it is expected that the Criminal Matters Amendment Bill [20 of 2015] will remove the current 20 year statute of limitation on the crime of torture.

${ }^{138}$ PMG report on the meeting of the Parliamentary Portfolio Committee on Justice and Correctional Services on 19 August 2015, available at: <https://pmg.org.za/committeemeeting/21350/> (last accessed 3 September 2015). 